\title{
SOSIALISASI HUKUM DALAM KEHIDUPAN MASYARAKAT
}

\author{
M. Mahrus Ali \\ Universitas Raden Rahmat Malang (UNIRA) \\ Email:mahrus@unira.ac.id
}

\begin{abstract}
The progress of a nation can be seen from the level of legal awareness of its citizens. The higher the legal awareness of the population of a country, the more orderly the life of society and state will be. This research has a problem formulation: What is the importance of legal socialization in society? What are the inhibiting factors for the socialization of law in society? Basically, the Indonesian people know and understand the law, but they are also consciously committing acts that violate the law. Narcotics users and dealers know that consuming and distributing narcotics against the law is a criminal act, but the fact is that the act is still being committed. The legal awareness of the Indonesian people is still weak which is synonymous with lawlessness. The next factor is the means or facilities that support law enforcement. Without certain means or facilities, it is impossible for the efforts to eradicate narcotics crime to proceed smoothly. These facilities or facilities include, among others, human resources, good organization, adequate equipment and space, adequate finance, and so on.
\end{abstract}

Keywords: Socialization, Law, Community Life

\section{PENDAHULUAN}

Dewasa ini banyak masyrakat Indonesia yang bingung terhadap hukum, padahal hukum sendiri adalah sebuah aturan yang di ciptakan untuk membuat kehidupan dapat berjalan -maksimal- ideal atau mendekati kehidupan yang ideal. berangkat dari intrumen hukum inilah yang kita usahakan agar hal tersebut dapat tercapai.

Namun bagaimana hal tersebut (kehidupan yang ideal) dapat tercapai jika hukum sendiri ternyata malah membuat masyarakat semakin bingung. berawal dari lambang yang di berikan orang-orang terhadap hukum yakni hukum di ibaratkan sebagai pedang yang di pegang oleh seorang wanita yang kedua matanya di tutup oleh kain, kalau kita kaji bersama anadaikan hukum di ibaratkan pedang dan di pegang oleh orang yang di tutup matanya bagaimana hukum itu akan dapat menjadi intrumen yang tepat bagi kita guna menuju kehidupan yang ideal, karena hukum sendiri dapat di gunakan sebagaimana dua mata pisau artinya ada pemikiran yang paradoks antara tujuan hukum yang ada dengan fakta realita di lapangan, jika hukum masih berada dalam keadaan abu-abu artinya dia tidak

This work is licensed under Creative Commons Attribution Non Commercial 4.0 International License Available online on: http://riset.unisma.ac.id/index.php/natiq/index 
mutlak sesuai kebutuhan maka hukum akan semakin membingungkan masyarakat, atau memang sengaja hukum di buat bertujuan seperti yang di gambarkan dalam patung ratu keadilan itu?

Bukan bermaksud memprovokasi tentang benar tidaknya keberadaan hukum khususnya di Indonesia ini, akan tetapi lebih kepada keinginan untuk mengajak masyarakat kita agar lebih peduli dengan keberadaan hukum itu sendiri, karena jika kita apatis terhadap hukum, maka jangan pernah berharap kehidupan yang ideal akan terlaksana, yakni kehidupan social yang penuh dengan nilai-nilai keadilan.

Jika kita ingin hukum itu benar-benar ada di tengah kita maka mari kita coba kaji dengan perlambangan hukum itu sendiri, pertama harusnya kita berfikir hukum bukanlah analogi dari sebuah pedang yang memiliki dua mata yang berlawanan, tapi kita harus berfikir bahwa hukum itu bagaikan payung yang siap memayungi siapa saja dalam keadaan apapun khususnya ketika terjadi hujanmasalah- jika hukum kita lambangkan dengan payung maka semua elemen masyarakat akan benar-benar terpayungi dengan adanya hukum. bukan sebaliknya masyarakat malah menjadi objek hukum yang sewaktu-waktu dengan gampangnya akan terkena jeratan hukum, jika hukum sudah seperti ini maka dapat dipastikan tidak akan ada tatanan kehidupan yang ideal di dalamnya. Dapat kita kaji pula hukum yang seperti apa yang dapat membawa kita dalam tatanan kehidupan yang ideal, pertama tentu hukum yang di ciptakan sesuai dengan kebutuhan dan keadaan yang sedang di hadapi oleh suatu masyarakat, agar hukum itu berjalan tanpa harus di dorong atau di paksa bahkan di bantah oleh masyarakat itu sendiri, dengan kata lain, mekanisme proses pembuatan hukum harus mencerminkan alam berpikir dan perilaku masyarakatnya, atau hukum itu harus representatif terhadap kehidupan sosial masyarakat.

Selanjutnya setelah kita semua dapat mengetahui arti penting dari sebuah hukum maka kita seharusnya mengetahui lebih dalam dan memahami tentang segala aturan hukum yang ada, dengan adanya hukum yang lebih memasyarakat itu akan dapat menjadikan hukum lebih memahami dari pada hanya sebuah aturan yang tidak mengena terhadap seluruh lapisan masyarakat.

Eksistensi Hukum dalam masyarakat yang dalam kepustakaan bahasa Inggris diistilahkan sebagai "Law in Society" atau dalam kurikulum berbagai program studi hukum di Indonesia diistilahkan dengan Sosiologi Hukum, merupakan salah satu cabang kajian tentang hukum sebagaimana adanya dalam kehidupan masyarakat. Beberapa akademisi menggolongkan kajian ini sebagai bentuk kajian hukum yang diperluas, sebagian lagimemasukkan cabang kajian ini kedalam rumpun ilmu pengetahuan sosial, apapun juga nomenklaturnya kajian ini adalah suatu cabang kajian yang seperti cabang kajian tentang kehidupan bermasyarakat pada umumnya, menyangkut upaya-upaya manusia dalam menegakkan dan mensejahterakan diri lewat kehidupan yang tertib dan terkontrol. 
Mempunyai perhatian yang lebih khusus, yang sedikit banyak telah membedakan diri dari kajian ilmu hukum yang klasik, tetapi juga membedakan diri cabang kajian ilmu-ilmu sosial yang lain. Kajian "Hukum dalam Masyarakat" ini hendak berfokus pada masalah otoritas dan kontrol yang memungkinkan kehidupan kolektif manusia itu selalu beradadalam keadaan yang relative tertib dan berketeraturan. Kekuatan control dan otoritas pemerintah sebagai pengemban kekuasaan negara yang mendasari control itulah yang kemudian disebut "Hukum" atau tepatnya diseyogyakan untuk disebut agak lengkap dengan istilah "Hukum Undang-Undang Nasional", maka dalam hubungan ini tidaklah keliru jika Black mendefinisikan hukum sebagai "Government's Social Control" (Donald Black, 1976:2-4)

Dalam kehidupan masyarakat pra-modern, ketika kehidupan itu masih berada pada skalanya dan formatnya yang lokal, homogen dan eksklusif, akan lebih sesuai untuk diistilahkan dengan komunitas (community) daripada masyarakat (society) atau bahkan masyarakat negara (political state). Apa yang disebut hukum ini umumnya tidak tertulis dan eksis sebagai azas-azas umum dalam ingatan warga komunitas, dirawat secara turun temurun sebagai tradisi yang dipercaya berasal dari nenek moyang. Inilah yang kemudian disebut tradisi atau moral kehidupan suatu komunitas yang dalam kajian sosiologi hukum disebut juga dengan hukum rakyat, dalam kajian ilmu hukum disebut dengan hukum kebiasaan atau hukum adat (Van den Bergh dalam von Benda-Beckman dan Fons Strijbosch, 1986:67).

Dalam perkembangan kehidupan yang lebih modern, ketika kehidupan bernegara dan berbangsa menggantikan pola kehidupan lokal yang berskala kecil dan eksklusif, apa yang disebut hukum itu mulai menampakkan wujudnya yang tertulis, inilah yang kemudian disebut dengan hukum undang-undang yang ditulis dalam rumusan-rumusan yang lebih eksak, dibentuk atau dibuat melalui prosedur tertentu, terstruktur atau terlembagakan sebagai sarana control yang nyata-nyata formal sifatnya, dalam konteks demikian maka selanjutnya otoritas kekuasaan yang memiliki kewenangan untuk mendayagunakan sanksi.

Dalam sejarah Eropa Barat, bersamaan dengan kebijakan pembentukan Undang-Undang Nasional dalam fungsinya sebagai standar perilaku warga negara, ketentuan-ketentuan undang-undang yang berjumlah banyak itu acapkali tidak dibiarkan tercerai berai melainkan dibukukan dan dinyatakan berlaku sebagai standar perilaku seluruh warga negara, selanjutnya difungsikan secara efektif sebagai kontrol sentral, dalam konteks inilah kemudian kajian-kajian hukum disebut kodifikasi dan unifikasi. Dengan demikian maka setiap ketentuan hukum harus diwujudkan dalam bentuk undang-undang agar aturan-aturan berperilaku dalam masyarakat akan dapat diniscayakan sehingga kepastian hukum yang berkeadilan dapat diwujudkan.

\section{Pengertian Hukum}

Dalam kehidupan masyarakat modern, hukum diartikan sebagai sebuah norma sosial yang diformalisasikan melalui institusi-institusi kekuasaan negara, 
sehingga cukup rasional untuk dikatakan bahwa hukum dalam modelnya sebagai undang-undang adalah invensi negara bangsa yang terjadi di Eropa Barat yang mengakhiri sejarah Eropa sebagai sejarah raja-raja yang dikenal dengan "The making Europe is the making of Kings and Queens no more, but the making of Nations".

Tumbuh berkembangnya negara-bangsa yang secara cepat atau lambat mengakhiri era kerajaan, telah berkonsentrasi pada kebutuhan akan suatu perangkat hukum baru, yaitu Hukum Nasional. Apabila hukum raja-raja dipandang sebagai hukum kaum elit-otokrat yang berbasis pada titah-titah sepihak penguasa, maka hukum nasional dibenarkan sebagai hukum yang lahir dari paradigma baru, bahwa suara rakyat yang disatukan secara rasional lewat kesepakatan dianggap sebagai suara Tuhan. (Vox Populi-Vox Dei). Hasil kesepakatan rakyat inilah baik secara langsung atau melalui wakil-wakilnya kelak pada gilirannya diinstitusionalisasi melalui lembaga legislatif.

Sebagai Hukum Nasional, hukum envensi Eropa-yang kelak menyebar ke seluruh dunia ditengarai memiliki sejumlah ciri atau karakteristik, antara lain (Harold Berman, 1983:77). Pertama, Hukum itu untuk diakui sebagai hukum formal, penegakannya harus dilakukan oleh aparat-aparat nasional dan ditegaskan dalam rumusan-rumusan tertulis, Kedua; Hukum Undang-Undang atau Doktrin Supremasi Hukum harus diterima sebagai pengganti mutlak berlakunya semua norma social yang hidup dalam masyarakat, dalam statusnya yang demikian maka Hukum Undang-Undang akan berlaku sebagai Hukum tertinggi, mengatasi norma sosial macam apapun.

Tercatat sebagai ciri karakteristik yang ketiga, adalah realita bahwa Hukum Nasional adalah hukum hasil kinerja manusia, oleh sebab itu memiliki cirri karakteristik khusus yang disebut "Historisitas", Hukum Nasional adalah adalah Hukum produk sejarah manusia, oleh sebab itu meski didoktrinkan dan diindoktrinasikan sebagai hukum "yang konon" akan dapat menjamin kepastianakan selalu saja disifati oleh cirri relativitas, karena itu pula Hukum akan mengalami perubahan dari masa ke masa.

Ciri Keempat, adalah bahwa hukum yang telah diformalkan sebagai hukum positif harus dikelola secara eksklusif oleh para ahli hukum dan sanggup bekerja secara kolektif di bawah kontrol suatu kode etik. Keahlian yang terkontrol oleh seperangkat norma etik yang telah dibukukan akan serta merta menjadikan para ahli hukum tersebut sebagai pakar hukum profesional. Keahlian dan etika inilah yang menjadikan para akar hukum itu terpercaya untuk merawat dan menjaga kewibawaan hukum.

Konsekuwen dengan aspek profesionalisme tersebut, sebagai ciri kelima, Hukum dalam eksistensinya sebagai suatu institusi kehidupan bernegara, memerlukan bantuan logistik dari dunia pendidikan universiter, tidak ada hukum nasional modern yang harus berfungsi melayani kehidupan bernegara dan berbangsa, yang tidak dirawat dan dikelola serta dikontrol perkembangannya oleh para profesional yang memperoleh keahlian dari lembaga-lembaga pendidikan 
akademik. Profesionalisme hukum dan pendidikan hukum adalah dua entitas yang saling melengkapi, sehingga dengan demikian memberikan karakteristik tersendiri kepada hukum nasional modern sebagaimana awalnya berkembang di Eropa Barat.

Hukum dan masyarakat keduanya seolah-olah merupakan pasangan yang tidak bisa terpisah, sebab berbicara tentang hukum pasti juga akan terkait dengan apa yang disebut masyarakat begitu sebaliknya karena hukum merupakan bagian dari proses sosial yang terjadi dalam masyarakat. Hukum tidak bisa terlepas dari pengaruh timbal balik dengan keseluruhan aspek yang ada dalam masyarakat, itulah sebabnya dikatakan bahwa hukum itu tidaklah otonom, dari sini terlihat bahwa hukum merupakan suatu realitas dalam masyarakat sehingga hukum disini lebih bersifar relistis dan empirik, yang mana hal ini sejalan seperti apa yang telah dikemukakan oleh Satjipto Raharjo (1983:37) bahwa "Saat ini hukum tidak lagi dilihat sebagai suatu hal yang sifatnya otonom dan independen, melainkan difahami secara fungsional dan dilihat senantiasa berada dalam kaitannya dengan interdependen dengan bidang-bidang lain dalam masyarakat.

Soetandyo (1986:75) mengatakan bahwa dimana kita bertemu dengan masyarakat manusia disitulah kita akan bertemu dengan sejumlah aturan karena tak ada masyarakat manusia dimanapun yang tak mengenal tata aturan/norma, dimana aturan tersebut diharapkan akan memberikan suatu keadilan, kedamaian, dan ketertiban bagi seluruh warga masyarakat tersebut. Maka untuk dapat mewujudkannya, hukum tidak akan bisa lepas dari tugas/fungsi yang diembankan pada hukum sebab untuk mencapai dan mewujudkan tujuan hukum maka hukum harus difungsikan menurut fungsi-fungsi tertentu bergantung pada apa yang hendak dicapai untuk mencapai kehidupan yang aman ,tentram, tertib dan adil dalam masyarakat, maka hukum harus dapat difungsikan dengan baik salah satu fungsi hukum yang dapat dilakukan adalah fungsi hukum sebagai kontrol sosial (pengendalian sosial) yakni bahwa hukum berfungsi untuk mempertahankan dan menjaga suatu keadaan pada suatu masyarakat agar tetap berada dalam pola tingkah laku yang diterima oleh masyarakat yang bersangkutan.

Menurut Satjipto Rahardjo (1983:87) bahwa hukum sebagai sarana kontrol sosial diartikan sebagai suatu proses mempengaruhi orang-orang untuk bertingkah laku yang sesuai dengan harapan masyarakat yang dapat dijalankan dengan berbagai cara, hal ini sejalan dengan apa yang dikatakan oleh Steven Vago bahwa "Sosial Control refers to the proceses and method used by members of a society or a group maintain social order by enforcing approved behavior" artinya bahwa kontrol sosial lebih ditujukan pada proses-proses atau caracara/mekanisme yang digunakan oleh masyarakat untuk menjamin penyesuaian dirinya terhadap norma-norna yang ada, dimana mekanisme tersebut disebut sebagai mekanisme kontrol sosial.

Cara atau mekanisme yang dapat dilakukan dalam pengendalian sosial menurut J.S.Roucek ditegaskan bahwa mekanisme kontrol sosial adalah segala sesuatu yang yang dijalankan untuk melaksanakan proses yang direncanakan atau 
tidak direncanakan untuk mendidik, mengajak atau bahkan memaksa warga masyarakat agar menyesuaikan diri dengan kebiasaan-kebiasaan dan nilai-nilai kehidupan masyarakat yang bersangkutan.

Dengan demikian dapat dikatakan bahwa proses pengendalian sosial dapat dilakukan dengan cara sebagai berikut:

a. Persuasif, yaitu tanpa paksaan, seperti mendidik, mengajak melalui proses sosialisasi. Cara ini lebih bersifat prefentif (pencegahan) terhadap terjadinya gangguan-gangguan pada keserasian dalam masyarakat.

b. Coercive, yaitu dengan paksaan/kekerasan, cara ini lebih bersifat represif yang berwujud seperti dengan penjatuhan sanksi pada warga yang melanggar/menyimpang dari kaidah-kaidah yang berlaku (Satjipto Rahardjo, 1983:167)

Namun demikian penerapan cara-cara tersebut tergantung pada faktor terhadap siapa dan dalam keadaan bagaimana hal tersebut dapat diperlakukan. Misalnya bila cara kekerasan begitu saja diterapkan pada suatu masyarakat tanpa melihat keadaannya maka bisa saja cara tersebut malah akan menimbulkan dampak yang negatif dimana ketaatan/kepatuhan masyarakat timbul hanya karna adanya faktor dari luar (outer) bukan berasal dari lubuk hatinya (inner) dimana kepatuhan yang berasal dari outwer tidak akan berlangsung lama.

Alat-alat yang digunakan dalam pengendalian social beraneka ragam, yang dalam pembahasan makalah ini difokuskan pada hukum nya sebagai alat kontrol sosial ,dimana telah dikemukakan sebelumnya bahwa hukum merupakan pedoman bagi manusia dalam bertingkahlaku/bergaul sehingga dengan pedomanpedoman tersebut manusia dapat mengontrol/mengendalikan perbuatannya agar tidak menyimpang dari aturan yang berlaku. Dalam hal ini tentunya selain diperlukan adanya peranan masyarakat juga peran dari aparat penegak hukumnya.

Menurut Ronny H.S Bahwa sosial kontrol merupakan aspek normatif dari kehidupan sosial dimana hukum sebagai alat kontrol sosial berfungsi unntuk menetapkan tingkah laku mana yang dianggap menyimpang dan sanksi serta tindakan apa yang dapat dilakukan oleh hukum terhadap penyimpangan tersebut hal ini sejalan dengan pendapat yang dikemukakan oleh Donald Black bahwa "Social control is the normative aspect of social life"

Dengan demikian dapat dikatakan bahwa tujuan utama yang hendak dicapai dengan adanya proses pengendalian sosial atau kontrol sosial adalah untuk mencapai keserasian di dalam masyarakat dan dengan keserasian tersebut akan tercipta suatu keadaan yang damai, adil dan tertib. Hukum sebagai kaidah positif yang merupakan dasar pembenar bagi para penguasa ataupun aparat penegak hukum dalam melaksanakan fungsi hukum sebagai cara untuk mengendalikan prilaku masyarakat (social control), tidak dapat dielakkan hubungannya yang teramat erat dengan dengan proses sosialisasi, karena sosialisasi merupakan suatu proses untuk menjadikan insan-insan sosial menjadi sadar akan adanya kaidah-kaidah hukum sehingga akan tercipta insan 
yang sanggup dengan sepenuh hati (to obey) atau setidak-tidaknya dapat menyesuaikan perilakunya (to conform) dengan ketentuan-ketentuan kaidah yang berlaku.

Sosialisasi juga merupakan suatu mekanisme dalam proses pengendalian sosial yang dikemukakan oleh Soerjono Soekanto diatas, sehingga dapat dikatakan bahwa sosialisasi ini perlu dilakukan untuk menunjang fungsi hukum sebagi social control karena agar hukum dapat mengendalikan pola tingkah laku manusia, untuk itu maka hendaknya manusia tersebut sadar terlebih dahulu akan betata pentingnya suatu aturan hukum yang kesadaran tersebut dapat ditumbuhkan melalui sosialisasi sehingga ia akan tau aturan apa yang harus ditaati dan sanksi

apa yang akan ditemui jika aturan tersebut tidak dipatuhi. Namun, tentunya suatu proses sosialisasi dalam fungsinya sebagi kontrol sosial tidak begitu saja berjalan mulus dan lancar, tetapi ada saja hal-hal yang menghambat pelaksanaan proses tersebut. Untuk itu dalam makalah ini penulis akan mengetengahkan dan mengkaji permasalahan yang terkait dengan hal tersebut dalam kacamata sosiologi hukum.

Melihat keterkaitan yang begitu erat antara sosialisasi dengan proses kontrol sosial, menimbulkan beberapa permasalahan terkait diantaranya: 1) Apakah pentingnya sosialisasi hukum dalam masyarakat? 2) Apakah faktor penghambat sosialisasi hukum dalam masyarakat?

\section{Urgensi Sosialisasi Hukum dalam Masyarakat}

Dalam kehidupan masyarakat dijumpai berbagai institusi yang masingmasing diperlukan untuk memenuhi kebutuhan-kebutuhan dan mempelancar jalanya pemenuhan kebutuhan tersebut. Oleh karena fungsi yang demikian itu maka masyarakat sangat membutuhkan kehadiran sebuah institusi penunjang, yaitu Institusi yang bergerak di sekitar kebutuhan tertentu manusia.

Apabila masyarakat telah mulai memperhatikan suatu kebutuhan tertentu maka akan berusaha agar dalam masyarakat dapat diciptakan suatu sarana untuk memenuhinya. Dalam tahapan inilah institusi tersebut dibangun. Jadi institusi pada hakikatnya merupakan alat pelengkap bagi masyarakat untuk menjamin agar kebutuhan-kebutuhannya dapat dipenuhi secara seksama. Dan, salah satuanya adalah persoalan Keadilan yang merupakan salah satu kebutuhan dalam hidup manusia. Adalah wajar jika aspek keadilan itu kemudian dikukuhkandalam institusi yang hukum, maka secara otomatis pada tahap berikutnya institusi hukum harus mampu menjadi sarana agar nilai keadilan diselenggarakan secara seksama dalam masyarakat. Beberapa ciri yang umumnya melekat pada institusi sebagai perlengkapan masyarakat:

1. Stabilitas. Kehadiran institusi hukum menimbulkan suatu keteraturan dalam usaha manusia untuk memperoleh keadilan.

2. Memberikan kerangka sosial terhadap kebutuhan dalam masyarakat. Dalam ruang lingkup kerangka yangt telah diberikan dan dibuat oleh masyarakat itu, anggota masyarakat dapat memenuhi semua kebutuhanya. 
3. Institusi menampilkan wujudnya dalam bentuk norma. Norma-norma inilah yang merupakan sarana untuk menjamin agar anggota-anggota masyarakat dapat dipenuhi kebutuhanya secara terorganisasi.

Hukum merupakan institusi sosial yang tujuannya untuk menyelenggarakan keadilan dalam masyarakat. Sebagai suatu institusi sosial, maka penyelenggaraanya bekaitan dengan tingkat kemampuan masyarakat. Oleh karena itu suatu masyarakat akan menyelengarakannya dengan cara tertentu yang berbeda dengan masyarakat yang lain. Perbedaan ini berhubungan erat dengan faktor sarana yang tersedia dalam masyarakat dan itu ini berarti adanya berhubungan yang erat antara institusi hukum suatu masyarakat dengan tingkat perkembangan organisasi sosialnya.

Hukum dalam masyarakat merupakan tuntutan, mengingat bahwa kita tidak mungkin menggambarkan hidup manusia tanpa atau di luar masyarakat. Maka manusia, masyarakat, dan hukum merupakan pengertian yang tidak bisa dipisahkan. Untuk mencapai ketertiban dalam masyarakat, diperlukan adanya kepastian dalam pergaulan antar-manusia dalam masyarakat. Kepastian ini bukan saja agar kehidupan masyarakat menjadi teratur akan tetapi akan mempertegas lembaga-lembaga hukum mana yang melaksanakannya.

Hukum yang baik adalah hukum yang sesuai dengan hukum yang hidup (the living law) dalam masyarakat, yang tentunya sesuai pula atau merupakan pencerminan dari nilai-nilai yang berlaku dalam masyarakat tersebut. Manusia dan hukum adalah dua entitas yang tidak bisa dipisahkan. Bahkan dalam ilmu hukum, terdapat adagium yang terkenal yang berbunyi: "Ubi societas ibi ius" (di mana ada masyarakat di situ ada hukumnya). Artinya bahwa dalam setiap pembentukan suatu bangunan struktur sosial yang bernama masyarakat, maka selalu akan dibutuhkan bahan yang bersifat sebagai "semen perekat" atas berbagai komponen pembentuk dari masyarakat itu, dan yang berfungsi sebagai "semen perekat" tersebut adalah hukum.

Untuk mewujudkan keteraturan, maka mula-mula manusia membentuk suatu struktur tatanan (organisasi) di antara dirinya yang dikenal dengan istilah tatanan sosial (social order) yang bernama: masyarakat. Guna membangun dan mempertahankan tatanan sosial masyarakat yang teratur ini, maka manusia membutuhkan pranata pengatur yang terdiri dari dua hal: aturan (hukum) dan si pengatur (kekuasaan).

Ketika Manusia sudah ada hubungan dengan Hukum maka hal yang harus dilakukan Manusia untuk terbebas dari jerat hukum adalah memperbaiki Nilai dan Moral karena ketika Nilai Moral sudah bagus, maka dorongan untuk melakukan kejahatan secara perlahan akan menghilang. Berikut adalah Beberapa pengaruh nilai dalam kehidupan sehari-hari:

1. Pengaruh Kehidupan Keluarga dalam Pembinaan Nilai Moral Keluarga berperan sangat penting bagi pembinaan nilai moral anak, hal ini karena dalam keluargalah, pendidikan pertama dan utama anak sebelum memasuki dunia pendidikan dan masyarakat. Kehidupan keluarga akan 
mempengarahi perkembangan jiwa dan nilai moral anak kedepannya, apabila dalam keluarga itu baik, maka anak itu juga akan baik, begitu juga sebaliknya.

2. Pengaruh Teman Sebaya terhadap Pembinaan Nilai Moral Pengaruh pergaulan dengan teman sebaya sangat mempengaruhi sikap dan perilaku generasi muda kitadalam hal moralnya. Apabila kita bergaulan dengan teman yang baik, maka kita juga terbawa kearah yang baik, begitu juga sebaliknya.

3. Pengaruh Figur Otoritas terhadap Perkembangan Nilai Moral Individu Pengaruh figure otoritas terhadap perkembangan nilai moral individu sangat besar pengaruhnya. Maka dari itu sosok seorang figur otoritas harus memberi contoh yang baik agar pemuda atau generasi yang ada dibawahnya bisa ikut meniru apa yang dilakukannya dan akhirnya akan membawa seseorang pemuda tersebut kearah yang baik juga.

4. Pengaruh Media Komunikasi terhadap Perkembangan Nilai Moral Pengaruh media telekomunikasi akhir-akhir ini memang cukup memprihatinkan di kalangan generasi muda. Penyalahgunaan sarana telekomunikasi yag seharusnya digunakan sesuai fungsinya ini cukup mempengaruhi sikap dan perilaku generasi muda kita.

5. Pengaruh media elektronik dan internet terhadap pembinaan nilai moral Seiring majunya teknologi, maka seluas itu juga semua informasi bisa diketahui dan bisa diakses langsung dengan yang namanya internet. Penyalahgunaan pemakaian elektronik maupun internet sangat mudah dijumpai apalagi di kalangan pemuda dan para remaja sekarang. Penyalahgunaan inilah yang nantinya juga bisa berakibat terhadap pembentukan nilai moral anak tersebut.

Sebelum kita mengetahui fungsi hukum, perlu kita dalami terlebih daluhu bahwa hukum mempunyai peranan sangat besar dalam pergaulan hidup atau bermasyarakat. Karena hal ini dapat dilihat dari ketertiban, ketenteraman dan tidak terjadinya ketegangan di dalam sosialisali hukum di masyarakat, karena hukumbersifat mengatur, menentukan hak dan kewajiban serta melindungi kepentingan individu dan kepentingan sosial. Dalam hal ini adapun fungsi hukum dalam kehidupan masyarakat seperti; menertibkan masyarakat dan pengaturan pergaulan hidup, menyelesaikan pertikaian, memelihara dan mempertahankan tata tertib dan aturan-aturan jika perlu dengan kekerasan, memelihara dan mempertahankan hak, mengubah tata tertib dan aturan-aturan dalam rangka penyesuaian dengan kebutuhan masvarakat, serta memenuhi tuntutan keadilan dan kepastian hukum. Selain itu juga fungsi hukum sebagi sarana ketertiban dan ketenteraman dalam masyarakat dan juga sebagai sarana untuk mewujudkan keadilan sosial lahir dan batin. 
Pada umumnya supaya fungsi hukum dapat terlaksana dengan baik, para pelaksanaan penegak hukum tentunya dituntut kemampuan untuk melaksanakan atau menerapkan hukum dengan seninya tersendiri, dengan cara menafsirkan hukum sedemikian rupa yang disesuaikan dengan keadaan dan posisi pihak-pihak. Bahkan bila perlu hukum dapat diterapkan dengan analogis atau menentukan kebijaksanaan untuk hal yang sama, atau hampir sama, serta penghalusan hukum. Selain tiu pula hal lain yang perlu diperhatiakn adalak faktor pelaksana penegak hukum, karena yang dibutuhkan dalam menegakkan hukum yang dibutuhkan adalah kecekatan, ketangkasan dan keterampilannya. Di samping fungsi hukum yang perlu diketahui pua adalah tujuan utama hukum adalah untuk menciptakan tatanan masyarakat yang tertib, menciptakan ketertiban dan keseimbangan dengan tercapainya ketertiban dan ketentraman dalam masyarakat dan diharapkan kepentingn manusia akan dpat terlindungi dalam mencapai tujuannya.

Karena fungsi hukum adalah membagi hak dan kewajiban antar perorangan di dalam masyarakat dan juga membagi wewenang serta mengatur cara memecahakan masalah hukum. Tidak hanya itu, tujuan serta fungsi hukum dalam kehidupan manusia yang semkain terus berkembang dengan sejalannya perkembangan masyarakat dimana hukum tersebut berada. Dan secra garis besarnya fungsi hukum sebagai sarana pengendalian sosial yaitu menjalankan tugas untuk mempertahankan ketertiban atau pola kehidupan dalam masyarakat. Kemudian perlu deketahui pula bahwa diadakannya hukum sama dengan tujuan Negara yang sesuai dengan bunyi Pembukaan Undang-Undang Dasar Negara RI Tahun 1945 yaitu untuk membentuk suatu Negara yang melindungi segenap bangsa dan seluruh tumpah darah di Indonesia serta untuk memajukan kesejahteraan umum, mencerdaskan kehidupan bangsa serta melaksanakan ketertiban dunia yang berdasarkan kemerdekan, perdamaian abadi, dan keadilan sosial. Yang artinya tujuan dan fungsi hukum ini adalah akat secara damai, untuk menjaga kepentingan tiap manusia agar tidak saling menggagu serta untuk menjamin kepstian hukum dalam kehidupan manusia sehari-hari di masyarakat. Nah untuk itu patuhilah hukum yang ada agar tujuan dan fungsi hukum tersebut dapat berjalan dengan baik.

\section{Faktor-Faktor Penghambat Sosialisasi Hukum dalam Masyarakat}

Sosialisasi hukum tidak selamanya berjalan dengan baik, salah satu faktor yang menjadi penghambat dalam proses sosialisasi hukum adalah stratifikasi social yang bersumber pada unsur kekuasaan dalam komunitas masyarakat. Suatu pengamatan terhadap masyarakat Secara sosiologis memeperlihatkan, bahwa kekuasaan itu tidak tebagi secara merata dalam masyarakat. Struktur pembagian yang demikian itu menyebabkan, bahwa kekuasaan itu terhimpun pada sekelompok orang-orang tertentu, sedangkan orang-orang lain tidak atau kurang memiliki kekuasaan itu. Keadaan seperti inilah yang menimbulkan perlapisan sosial di dalam masyarakat. Bagaimana struktur yang berlapis-lapis itu bisa terbentuk banyak tergantung dari sistem perekonomian suatu masyarakat. 
Terjadinya penumpukan kekuasaan di tangan sekelompok orang-orang tertentu berhubungan dengan sistem pembagian sumber daya dalam masyarakat. Kekuasaan itu tidak terlepas dari penguasaan barang-barang dalam masyarakat. Oleh karena itu terjadinya perlapisan kekuasaan berhubungan erat dengan barang-barang yang bisa dibagi-bagikan itu tentunya susah dibayangkan timbulnya perlapisan sosial dalam masyarakat.

Para ahli sosiologi hukum memberikan perhatian besar terhadap hubungan antara hukum dengan perlapisan sosial ini. Dengan terjadinya perlapisan sosial maka hukum pun susah untuk memperhatikan netralitas atau kedudukannya yang tidak memihak. Perlapisan sosial ini merupakan kunci penjelasan mengapa hukum itu bersifat diskriminatif, baik pada peraturan-peraturannya sendiri, maupun melalui penegakannya. Para ahli tersebut di muka berpendapat, bahwa peraturanperaturan hukumnya sendiri tidaklah memihak. Dalam keadaan yang demikian ini pendapat yang berkuasapun akan menentukan bagaimana isi peraturan hukum dibuat.

Dengan demikian, harus diusahakan agar penegakan hukum itu tidak memihak, namun karena sudah sejak kelahirannya peraturan-peraturan itu tidak representatif, maka hukum pun bersifat memihak, keadaan yang demikian itu juga dijumpai pada masalah penegakan hukum. Kalaulah kita sekarang sudah mengetahui betapa besar peranan hukum di dalam membantu menciptakan ketertiban dan kelancaran dalam kehidupan masyarakat, kita masih saja belum mengetahui benar apa yang dikehendaki oleh hukum tersebut. Apakah sekedar untuk menciptakan ketertiban atau lebih jauh daripada itu?

Pertanyaan atau masalah ini layak sekali untuk mendapatkan perhatian kita. Apabila kita mengatakan, bahwa hukum-hukum itu bermaksud untuk menciptakan ketertiban, maka sebetulnya kita hanya berurusan dengan hal-hal yang bersifat dengan hal-hal teknik. Melarang orang untuk melakukan pencurian dengan menciptakan suatu hukum dengan sanksinya adalah suatu usaha yang bersifat teknik. Tapi mengapa justru mencuri itu yang dilarang? Jawabanya adalah, karena mencuri itu dianggap sebagai perbuatan yang tercela oleh masyarakat. Dengan demikian, kita telah memasuki bidang yang tidak teknik lagi sifatnya, melainkan sudah ideal.

Pembicaraan ini diharapkan dapat memberikan wawasan yang lebih sesuai dengan kenyataan dalam kita meninjau dan mempelajari hukum, yaitu bahwa hukum itu hadir dalam masyarakat karena harus melayani kebutuhan-kebutuhan tertentu dan harus mengolah bahan-bahan tertentu yang harus ia terima sebagai suatu kenyataan. Karena hukum itu memberikan pembatasan-pembatasan yang demikian itu maka institusi hukum itu hanya bisa berjalan dengan seksama di dalam suatu lingkungan sosial dan politik yang bisa dikendalikan secara efektif oleh hukum. Suatu masyarakat yang berkehendak untuk diatur oleh hukum tetapi yang tidak bersedia untuk membiarkan penggunaan kekuasaannya dibatasi dan dikontrol, bukan merupakan lingkungan yang baik bagi berkembangnya institusi hukum. 
Mengakui adanya ciri historisitas yang melekat pada eksistensi hukum Undang-Undang, orang pada dasarnya akan segera tersadar bahwa Hukum Nasional itu tidak akan berkepastian tinggi sebagaimana yang diperlihatkan hukum-hukum empirik, adagium kepastian hukum yang menurut doktrinnya dilekatkan pada eksistensi Hukum Undang-Undang positif itu sebenarnya merupakan suatu pernyataan yang bersifat relatif. Sepanjang sejarah, hukum akan berubah sejalan perubahan zaman, dari kajian hukum positif ini pulalah lahirnya kajian hukum dalam masyarakat yang berfokus pada kajian text in context.

Kajian-kajian tekstual terhadap hukum berkembang dengan sebutan jurisprudential sepanjang abad ke 18 hingga abad ke 19, kajian ini banyak berimprovisasi dengan upaya yang sistematik dari produk perundang-undangan berikut prosedur-prosedur pendayagunaannya, ditunjang juga oleh ajaran-ajaran yang menjadikan preskripsi-preskripsi undang-undang yang terorganisasi ke dalam suatu sistem yang logis dan koheren (Dragan Milovanovich, 1976, 2-4). Kajian terkstual terhadap hukum berjalan seiring dengan perubahan kehidupan sosial yang terjadi dalam masyarakat. Gilin menyatakan perunahan-perubahan sosial adalah suatu variasi dan cara-cara hidup yang telah diterima baik karena perubahan-perubahan kondisi geografis, kebudayaan material, ideologi maupun karena adanya digusi ataupun penemuan-penemuan baru dalam masyarakat. Secara singkat, Samuel Koeng menyatakan bahwa perubahan social menunjuk pada modifikasi-modisikasi yang terjadi pada pola-pola kehidupan manusia, modifikasi-modifikasi mana terjadi karena sebab-sebab intern maupun ekstern (Samuel Koening, 1957:279).

Lebih jauh Selo Soemarjan dalam (Soerjono Soekanto, 1995:337) merumuskan bahwasanya perubahan sosial adalah segala perubahan-perubahan pada lembaga-lembaga kemasyarakatan dalam suatu kehidupan masyarakat yang mempengaruhi sistem sosialnya termasuk didalamnya kaidah-kaidah hukum yang dianut, nilai-nilai, sikap dan perilaku diantara kelompok-kelompok dalam masyarakat.

Adalah suatu kenyataan bahwa transisi-transisi transformatif yang pesat dan transparan sebagai realita sosiologis tidak bisa secara cepat diimbangi oleh pembaharuan dalam seluruh tatanan perundang-undangan. Dengan kata lain, aturan-aturan lama yang mendasarkan pada ketentuan-ketentuan preskripsi lama tidak sepenuhnya mampu memberikan solusi atas permasalahan-permasalahan baru yang muncul seiring dengan berkembangnya perubahan kehidupan sosial dalam masyarakat

Pendayagunaan kajian sosiologik inilah yang kemudian memperkuat daya kerja ilmu hukum, dari kajian-kajian hukum murni yang mengkaji hukum dengan keyakinan yang doctrinal namun sempit akan eksistensi ilmu hukum sebagai ilmu yang tersendiri (Sui Generis) menjadi suatu studi yang sangat luas. Membuka diri untuk memanfaatkan hasil kajian-kajian ilmu sosial yang marak sejak belahan akhir abad ke-19, dan pada abad ke-20, ilmu hukum memiliki karakternya yang baru yang disebut "in between jurisprudence" (Dragon Milovanovich, 1994:227). 
Istilah "between jurisprudence" ini memang mengundang kontroversi, apakah kajian hukum dalam masyarakat itu sesungguhnya terbilang ilmu hukum (jurisprudence) atau sudah bergeser menjadi kajian yang lebih masuk ke ranah ilmu-ilmu sosial yang lebih empirik dengan fokus kajian yang berarah ke persoalan "apa yang terjadi" dan "mengapa sampai terjadi", daripada yang normatif dan/atau preskriptif dengan fokus kajiannya yang berarah ke persoalan "bagaimana seharusnya bertindak". Pendapat yang menolak kajian "in between jurisprudence sebagai kajian hukum menyebut kajian yang berada di wilayah abu-abu ini sebagai kajian sosiologi hukum, sementara yang menerima kajian yang satu ini sebagai kajian imu tentang hukum menyebutnya dengan istilah "Hukum dalam Masyarakat".

\section{PENUTUP}

Kemajuan suatu bangsa dapat dilihat dari tingkat kesadaran hukum warganya. Semakin tinggi kesadaran hukum penduduk suatu negara, akan semakin tertib kehidupan bermasyarakat dan bernegara. Faktor kesadaran hukum ini mempunyai peran penting dalam perkembangan hukum artinya semakin lemah tingkat kesadaran masyarakat, semakin lemah pula kepatuhan hukumnya sebaliknya semakin kuat kesadaran hukumnya semakin kuat pula faktor kepatuhan hukum. Kesadaran hukum masyarakat yang pada gilirannya akan menciptakan suasana penegakan hukum yang baik, yang dapat memberikan rasa keadilan, menciptakan kepastian hukum dalam masyarakat dan memberikan kemanfaatan bagi anggota masyarakat.

Pada dasarnya masyarakat Indonesia tahu dan paham hukum, tetapi secara sadar pula mereka masih melakukan perbuatan-perbuatan melanggar hukum. Para pemakai dan pengedar narkotika tahu bahwa mengkomsumsi dan mengedarkan narkotika secara melawan hukum adalah tindak pidana, tetapi faktanya perbuatan itu masih tetap dilakukan. Kesadaran hukum masyarakat Indonesia masih lemah yang identik dengan ketidaktaatan hukum.

Upaya sosialisasi hukum kepada masyarakat juga harus terus dilakukan untuk meningkatkan kesadaran hukum masyarakat. Sosiologi hukum sangat berperan dalam upaya sosialisasi hukum demi meningkatkan kesadaran hukum yang positif, baik dari warga masyarakat secara keseluruhan, maupun dari kalangan penegak hukum. Sosialisasi merupakan salah satu aspek penting dalam proses kontrol sosial sebab untuk dapat mempengaruhi orang-orang agar bertingkah laku sesuai dengan kaidah-kaidah hukum berlaku.

Faktor berikutnya adalah sarana atau fasilitas yang mendukung penegakkan hukum. Tanpa adanya sarana atau fasilitas tertentu, maka tidak mungkin upaya pemberantasan tindak pidana narkotika berlangsung dengan lancar. Sarana atau fasilitas tersebut antara lain mencakup sumber daya manusia, organisasi yang baik, peralatan dan tempat yang memadai, keuangan yang cukup, dan seterusnya. 


\section{DAFTAR RUJUKAN}

Achmad Ali, 2002. Menguak Tabir Hukum (Suatu Kajian Filosofis dan Sosiologi), Jakarta: P.T. Toko Gunung Agung

-----------, 2002. Keterpurukan Hukum di Indonesia (Penyebab dan Solusinya), Jakarta: Ghalia Indonesia.

Ali Aspandi, tt. Menggugat Sistem Hukum Peradilan Indonesia yang Penuh Ketidakpastian, Surabaya: LeKSHI

Donald Black, 1976. The Behavior of Law. London: Academic Press.

Dragan Milovanovich, 1976. The Bahavior of Law. London: Academic Press.

Dragon Milovanovich, 1994. A Premier in The Sociology of Law, New York: Harrow and Heston.

Harold Berman. 1983. "Law and Revolution": The Formation of Western legal Tradition. Cambridge, Mass: Harvard Univ. Press.

Marc Galanter, 1966. "Modern Law" dalam Myron Weiner (ed) Modernization, The Dynamics of Growth. Washington DC, Voice of America Forum Lectures.

Samuel Koening, 1957. Man and Society, The Basic Teaching of Sociology, New York, Borness van Noble Inc.

Satjipto Rahardjo. 1983. Hukum dan Perubahan Sosial, Edisi Pertama, Bandung: Alumni.

Soetandyo Wignjosoebroto, 1986. Hukum, Paradigma, Metode dan Dinamika Masalahnya, Jakarta: Elsan \& Huma.

Soerjono Soekanto, 1995. Sosiologi: Suatu Pengantar, Jakarta: Rajawali Pers.

Rachmad Budiono, 1999. Memahami Hukum, Malang: Fakultas Hukum Universitas Brawijaya.

Soerjono Soekanto, 2000. Pokok-pokok Sosiologi Hukum. Jakarta: PT.Raja Grafindo Persada.

--------------, 2002. Faktor-faktor yang Mempengaruhi Penegakan Hukum, Jakarta: PT Raja Grafindo Persada.

-----------, 2001. Pengantar Sosiologi, Jakarta: PT.Raja Grafindo Persada,

Van den Bergh. 1986. "The Concepts of Folklaw in Historical Context, a Brief Outline" dalam Keebet von Benda-Beckman dan Fons Strijbosch (ed) Anthropology of Law in The Netherlands. Dordrecht: Foris Publications.

http://kelompok4isbd.wordpress.com/2012/04/12/makalah-ilmu-sosial-danbudaya-dasar-manusia-nilai-moral-dan-hukum/

http://ilmubudayadasar-wanda.blogspot.com/2011/12/sumber-sumberhukum.html

http://www.siputro.com/2013/02/fungsi-hukum-dalam-kehidupan-masyarakat/ http://kubuskecil.blogspot.com/2013/01/peranan-hukum-dalam-sosialmasyarakat.html 